International Journal of Agriculture, Environment and Bioresearch

Vol. 4, No. 05; 2019

ISSN: $2456-8643$

\title{
EVALUATION OF PRODUCTIVITY OF CHLORIS GAYANA UNDER SOILS OF VARYING COMPOSITION IN SOUTH WESTERN UGANDA
}

\author{
Morgan Andama $^{{ }^{*}}$, Charles Lagu ${ }^{2}$ and Robert Muzira ${ }^{3}$ \\ ${ }^{1}$ Department of Biology, Muni University, P.O.Box725, Arua, Uganda \\ ${ }^{2}$ National Animal Genetic Resources Centre and Data Bank (NAGRC\&DB), Entebbe, Uganda \\ ${ }^{3}$ National Agricultural Research Organisation (NARO) \\ *Corresponding Author: m.andama@muni.ac.ug
}

http://doi.org/10.35410/IJAEB.2019.4443

\begin{abstract}
This study therefore evaluated the productivity of Chloris gayana under varying soils in South Western Uganda. The productivity of Chloris gayana in selected districts in South Western Uganda (Kiruhura, Ibanda, Mbarara, Isingiro, Sheema) was already established by Lagu et al (2017). The present study profiled the soils in the above districts where the Chloris gayana was grown for total organic matter, available phosphorus, extractable bases (potassium, sodium, magnesium and calcium), total nitrogen and textural classes (sand, clay, silt) following standard procedures described by Okalebo et al (2002). The results showed that the highest quantity of seeds and biomass per acre of Chloris gayana grass is attained if only all the essential primary soil nutrients $(\mathrm{N}, \mathrm{P}, \mathrm{K})$ are above the critical levels. Hence, Kiruhura district having soils with the highest levels of essential soil nutrients, $\mathrm{N}(4.00 \pm 0.77 \%), \mathrm{P}(33.73 \pm 12.98 \mathrm{ppm})$ above the critical levels $(\mathrm{N}, 2 \% ; \mathrm{P}, 15 \mathrm{ppm})$ recorded the highest quantity of Chloris gayana seeds harvested per acre $(18.03 \pm 3.03 \mathrm{~kg}$ per acre) and hay bales per acre (311.11 kg/acre) compared to the other districts. Hence, efforts towards soil testing and soil amendments with essential nutrients (NPK) need to be intensified for increased productivity of Chloris gayana in South Western Uganda.
\end{abstract}

Keywords: Hay bales, Nutrients, Rhodes grass, Seeds.

\section{INTRODUCTION}

In Uganda, the livestock subsector plays a significant role as it is a source of livelihood to about 4.5 million people and contributes about 3.2\% of the Gross Domestic Product (GDP) of the country (Mbabazi and Ahmed 2012; UIA 2009; ICPALD 2013). The cattle kept provide a reliable source of income, household nutrition/ food security and employment; among other benefits (ACET 2017). However, agriculture and livestock production is characterized by low yields, shortage of water and pastures/ forages including pasture seeds especially in the dry areas of the cattle corridor (World Bank 2011; MAAIF 2010). Hence there is increased demand for improving rangelands in pastoral areas including the South Western Zone of Uganda to boost livestock productivity. One strategy is to demonstrate community seed multiplication, pasture establishment and improvement and utilization of improved forages like Rhodes grass in the dry 
livestock corridor. This is because of the increasing popularity of Rhodes grass and its suitability for making hay for all kinds of stock (Arshad et al 2014, 2016).

Rhodes grass (Chloris gayana Kunth), a native to sub-Saharan Africa (e.g. Uganda, Ethiopia, Sudan, Kenya and Tanzania etc) is one of the $\mathrm{C} 4$ forage perennial grasses which is used as pasture and hay crop (Osman et al 2014).By growing Rhodes grass farmers can produce more feed for their livestock since it has better productivity and nutritive value compared to natural pasture such as Cymbopogan spp., Themedra triandra, Brachiaria spp., Panicum Maximum, and Hyperrrhenia spp etc (Duke 1978; Abebe et al 2015; Meat Master Plan 1998). However, most rangelands are degraded by over stocking and over grazing leading to land degradation (Kashaigili et al 2015) hence low soil fertility for growth of Rhodes grass. One of the ways of boosting pasture (Rhodes grass) productivity is to routinely examine the elements in soils to determine nutrient levels for better yields as Rhodes grass is productive in moderate to high fertile soils (Horneck et al 2011; Abebe et al 2015). The chemical composition of a pasture is also influenced by soil fertility, soil moisture among other factors (Mwale 1993). The commonly tested primary macro nutrients required in large amounts are $\mathrm{N}$, phosphorus $(\mathrm{P})$, potassium $(\mathrm{K})$ while the secondary macro nutrients are $\mathrm{Ca}$ and Mg. Dinkins and Jones (2013) observed that many plant deficiencies are mainly due to $\mathrm{N}, \mathrm{P}$ and $\mathrm{K}$. For instance, pastures growing on soils with low $\mathrm{P}$ levels (less than $10 \mathrm{ppm}$ or $10 \mathrm{mg} / \mathrm{kg}$ ) were found to have inadequate $\mathrm{P}$ for beef production hence the animals would directly suffer from $\mathrm{P}$ deficiency unless $\mathrm{P}$ supplements were given or pasture was fertilized (Cook 2014).

The functional roles of calcium is that it is a major structural component of the cell walls; Magnesium plays a central building block in the structure of chlorophyll and Potassium is required by all living organisms, normally in relatively large amounts and is part of the plant structural tissues (Marschner1995; Lavelle and Spain, 2001). Another important mineral micronutrient is Sodium which is essential in plants e.g. Chloris gayana that undergo C4 photosynthetic pathway. Further still, Soil organic matter (OM) enhances soil biological activity and productivity and has effects on a number of soil mineral nutrients and physical properties (Nanzyo et al 1993).

However the soil nutrient compositions and their effect on the productivity of Rhodes grass has not yet been done in South Western Uganda. Therefore the objective of the study was to evaluate the productivity of Chloris gayana under soils of varying composition in South Western Uganda.

\section{MATERIALS AND METHODS}

The study districts in South Western Uganda included Kiruhura, Ibanda, Mbarara, Isingiro and Sheema. The details of the Study location, design and sampling as well as the determination of Chloris gayana productivity are found in Lagu et al (2017). This section only describes the sampling and analysis of soil parameters from the study districts. 


\subsection{Field selection}

Fields under pasture study were selected with the help of the farmers and extension workers. Composite samples were obtained from several sub samples from seemingly uniform field. Soil samples were taken in diagonal patterns to form one composite sample (Ryan et al 2001). On the other hand, for fields that were heterogeneous, several samples were obtained. Information such as cropping patterns, soil fertility management practices and previous history of the fields were obtained from targeted farmers. To avoid biases with the laboratory results, areas in the fields under trees, near roads or foot paths and heaps of crop residues or manure were avoided. Correspondingly, more samples were taken where manure and/or crop-livestock systems were practiced. To obtain uniformity, sampling was done using a soil auger.

\subsection{Field processing}

Soils from each field samples were placed in a clean basin and uniformly mixed while breaking clods and removing stones, roots and organic matter that is not decomposed. Quarter sampling was done on soils placed in the basin until approximately $0.5 \mathrm{~kg}$ of the soils was obtained. The samples were then placed in plastic bags that were labeled indicating farmer's name, cropping history and fertility management.

\subsection{Analysis of soil parameters}

All the information about the soil samples was recorded, and each sample was given a laboratory number. The samples were air-dried in open air under a shed at room temperature of $25-30{ }^{\circ} \mathrm{C}$. When dried, the samples were cleaned off any stones and plant residues. The samples were then ground in porcelain mortar and screened through a 2-mm sieve and kept in labeled plastic bottles. The bottled samples were given numbers before the samples were analyzed following procedures described by Okalebo et al (2002). The samples were analyzed for $\mathrm{pH}$, total organic matter, available phosphorus, extractable bases (potassium, sodium, magnesium and calcium), total nitrogen and textural classes (sand, clay, silt).

\subsection{Data analysis}

Data on soil profiles and yields for Chloris gayana seeds and hay bales per acre were entered into Microsoft Excel 2007 spreadsheets and exported into SPSS Version 20. Data was cleaned and analyzed for range (minimum, maximum) values, mean, and standard error (SE) of the mean and results tabulated. Comparison of Chloris gayana yield data and soil parameters in the various districts were established using ANOVA ( $\mathrm{F}$ test) and student $\mathrm{t}$ test. Relationships between soil parameters and Chloris gayana yield were ascertained using Pearson correlation coefficient (r). The inferential statistical tests were performed at $5 \%$ level of significance.

\section{RESULTS}

The mean $\mathrm{pH}$ values in all the districts ranged from 5.86-6.79 with the highest mean $\mathrm{pH}$ recorded in soils of Ibanda while the least $\mathrm{pH}$ was registered in Isingiro (Table 1). The highest mean level 
of organic matter $(\mathrm{OM})$ was recorded in Mbarara district (4.38\%) while the least was in Isingiro $(0.16 \%)$.

Nitrogen fluctuated between 0.11 to $4.00 \%$ in Sheema and Kiruhura districts respectively with concentrations in Sheema, Mbarara and Ibanda being lower than the critical value (2\%) while Isingiro and Kiruhura had $\mathrm{N}$ concentrations above the critical value. Phosphorus ranged from 13.89 to $33.73 \mathrm{ppm}(0.0014-0.0034 \%)$ in Sheema and Kiruhura districts respectively with lower mean concentrations than the critical value $(15 \mathrm{ppm})$ in Sheema district while concentrations in the other districts are above the critical level.

The results of basic cation (calcium, magnesium, potassium, and sodium) concentrations in soils of the study districts showed that mean Ca ranged from 0.81 to $6.38 \mathrm{cmoles} / \mathrm{kg}(0.032-0.256 \%)$ in Isingiro and Mbarara districts respectively. The highest mean concentration of magnesium (3.58 cmoles $/ \mathrm{kg}$ or $0.087 \%$ ) was recorded in Kiruhura while the least Mg level $(1.14 \mathrm{cmoles} / \mathrm{kg}$ or $0.028 \%$ ) was found in Sheema. $\mathrm{Ca} / \mathrm{Mg}$ ratio in the study districts fluctuated between 0.24 and 4.14 in Isingiro and Mbarara respectively. There was difference in $\mathrm{Ca} / \mathrm{Mg}$ ratios in soils of the study districts $(\mathrm{p}<0.05)$. Mbarara district registered the highest mean concentrations of potassium $(1.05$ cmoles $/ \mathrm{kg}$ or $0.041 \%)$ and sodium $(0.23$ cmoles $/ \mathrm{kg}$ or $0.0053 \%)$ while Isingiro had the least levels of potassium $(0.83$ cmoles $/ \mathrm{kg}$ or $0.032 \%)$ and sodium $(0.12 \mathrm{cmoles} / \mathrm{kg}$ or $0.0028 \%)$. The levels of $\mathrm{K}$ and $\mathrm{Mg}$ in soils of the study districts were all above the critical concentrations of $\mathrm{K}(0.2-0.3 \mathrm{cmoles} / \mathrm{kg})$ and $\mathrm{Mg}(0.4 \mathrm{cmoles} / \mathrm{kg})$ for Chloris gayana, a tropical grass. The mean concentrations of Cain soils were higher than the critical value $(1.00 \mathrm{cmoles} / \mathrm{kg})$ in Kiruhura, Ibanda, Mbarara and Sheema districts while the mean $\mathrm{Ca}$ amounts were below the critical level in Isingiro district.

Table 1:Chloris gayana yields in relation to soil parameters across the south Western zone of Uganda

\begin{tabular}{|c|c|c|c|c|c|c|c|}
\hline Study Districts & $\begin{array}{l}\text { Kiruhura, } \\
\text { seed }(\mathrm{N}=21) \text {, } \\
\text { bale }(\mathrm{N}=1) \text {, soil } \\
(\mathrm{N}=8)\end{array}$ & $\begin{array}{l}\text { Ibanda, } \\
\text { seed }(\mathrm{N}=3) \text {, } \\
\text { soil }(\mathrm{N}=8)\end{array}$ & $\begin{array}{l}\text { Mbarara, } \\
\text { seed }(\mathrm{N}=5) \text {, bale } \\
(\mathrm{N}=2) \text {, soil }(\mathrm{N}=8)\end{array}$ & $\begin{array}{l}\text { Isingiro, } \\
\text { seed }(\mathrm{N}=4), \\
\text { soil }(\mathrm{N}=8)\end{array}$ & $\begin{array}{l}\text { Sheema, } \\
\text { seed }(\mathrm{N}=3) \text {, } \\
\text { soil }(\mathrm{N}=5)\end{array}$ & \multirow[t]{2}{*}{$F^{\prime}$ or t' } & \multirow[t]{2}{*}{$\mathrm{p}$} \\
\hline & $\begin{array}{l}\text { Range } \\
(\text { Mean } \pm \text { SE })\end{array}$ & $\begin{array}{l}\text { Range } \\
(\text { Mean } \pm \text { SE })\end{array}$ & $\begin{array}{l}\text { Range } \\
(\text { Mean } \pm \text { SE })\end{array}$ & $\begin{array}{l}\text { Range } \\
(\text { Mean } \pm \text { SE })\end{array}$ & $\begin{array}{l}\text { Range } \\
(\text { Mean } \pm \text { SE })\end{array}$ & & \\
\hline $\begin{array}{llr} & \begin{array}{l}\text { a Quantity } \\
\text { of }\end{array} & \text { seeds } \\
\text { harvested } & (\mathrm{Kg}) & \text { per } \\
\text { acre } & & \end{array}$ & $\begin{array}{l}6.00-55.00 \\
(18.03 \pm 3.03)\end{array}$ & $\begin{array}{l}5.00-20.00 \\
(11.25 \pm 4.51)\end{array}$ & $\begin{array}{l}5.71-23.86 \\
(15.62 \pm 3.17)\end{array}$ & $\begin{array}{l}2.90-15.00 \\
(10.98 \pm 2.76)\end{array}$ & $\begin{array}{l}7.00-14.00 \\
(10.33 \pm 2.03)\end{array}$ & $1.425^{\prime}$ & 0.228 \\
\hline $\begin{array}{l}\text { aQuantity of } \mathrm{Hay} \\
\text { Bales harvested }(\mathrm{Kg}) \\
\text { per acre }\end{array}$ & $\begin{array}{l}311.11-311.11 \\
(311.11)\end{array}$ & - & $\begin{array}{l}250.00-342.86 \\
(296.43 \pm 46.43)\end{array}$ & - & - & $0.183^{\prime \prime}$ & 0.885 \\
\hline $\begin{array}{ll}\text { Soil } & \text { Critical } \\
\text { parameters } & \text { values }\end{array}$ & & & & & & & \\
\hline & $\begin{array}{l}5-6.3 \\
(5.96 \pm 0.15)\end{array}$ & $\begin{array}{l}6.26-7.59 \\
(6.79 \pm 0.13)\end{array}$ & $\begin{array}{l}5.54-7.69 \\
(6.55 \pm 0.23)\end{array}$ & $\begin{array}{l}5.10-6.60 \\
(5.86 \pm 0.17)\end{array}$ & $\begin{array}{l}5.80-6.10 \\
(5.92 \pm 0.07)\end{array}$ & $6.341^{\prime}$ & 0.001 \\
\hline $\mathrm{OM}(\%)$ & $\begin{array}{l}0.09-0.39 \\
(0.20 \pm 0.03)\end{array}$ & $\begin{array}{l}2.48-4.16 \\
(3.46 \pm 0.23)\end{array}$ & $\begin{array}{l}1.63-9.30 \\
(4.38 \pm 1.12)\end{array}$ & $\begin{array}{l}0.11-0.22 \\
(0.16 \pm 0.01)\end{array}$ & $\begin{array}{l}2.49-3.24 \\
(2.84 \pm 0.14)\end{array}$ & $12.983^{\prime}$ & 0.000 \\
\hline $\mathrm{N}(\%)$ & $\begin{array}{l}1.8-8.3 \\
(4.00 \pm 0.77)\end{array}$ & $\begin{array}{l}0.13-0.20 \\
(0.17 \pm 0.01)\end{array}$ & $\begin{array}{l}0.08-0.93 \\
(0.32 \pm 0.10)\end{array}$ & $\begin{array}{l}2.40-4.64 \\
(3.21 \pm 0.29)\end{array}$ & $\begin{array}{l}0.08-0.13 \\
(0.11 \pm 0.01)\end{array}$ & $21.767^{\prime}$ & 0.000 \\
\hline
\end{tabular}




\section{International Journal of Agriculture, Environment and Bioresearch}

Vol. 4, No. 05; 2019

ISSN: $2456-8643$

\begin{tabular}{|c|c|c|c|c|c|c|c|c|}
\hline $\begin{array}{l}\text { Av.P (ppm) } \\
(\mathrm{mg} / \mathrm{kg})\end{array}$ & $15^{\mathrm{c}}$ & $\begin{array}{l}2.7-104.20 \\
(33.73 \pm 12.98)\end{array}$ & $\begin{array}{l}0.28-74.36 \\
(27.59 \pm 9.04)\end{array}$ & $\begin{array}{l}0.11-53.50 \\
(23.97 \pm 6.38)\end{array}$ & $\begin{array}{l}2.34-90.74 \\
(17.44 \pm 10.60)\end{array}$ & $\begin{array}{l}6.83-20.27 \\
(13.89 \pm 2.53)\end{array}$ & $0.604^{\prime}$ & 0.663 \\
\hline $\begin{array}{l}\mathrm{Ca} \\
(\mathrm{cmoles} / \mathrm{kg})\end{array}$ & $1.00^{\mathrm{c}}$ & $\begin{array}{l}0.46-2.26 \\
(1.20 \pm 0.26)\end{array}$ & $\begin{array}{l}3.75-10.75 \\
(6.50 \pm 0.77)\end{array}$ & $\begin{array}{l}0.75-17.25 \\
(6.38 \pm 2.32)\end{array}$ & $\begin{array}{l}0.27-1.91 \\
(0.81 \pm 0.21)\end{array}$ & $\begin{array}{l}2.00-3.00 \\
(2.55 \pm 0.20)\end{array}$ & $5.682^{\prime}$ & 0.001 \\
\hline $\begin{array}{l}\mathrm{Mg} \\
(\mathrm{cmoles} / \mathrm{kg})\end{array}$ & $0.4^{\mathrm{c}}$ & $\begin{array}{l}0.91-8.75 \\
(3.58 \pm 0.93)\end{array}$ & $\begin{array}{l}0.91-2.80 \\
(1.63 \pm 0.20)\end{array}$ & $\begin{array}{l}0.20-4.00 \\
(1.52 \pm 0.54)\end{array}$ & $\begin{array}{l}1.80-5.70 \\
(3.36 \pm 0.61)\end{array}$ & $\begin{array}{l}0.90-1.50 \\
(1.14 \pm 0.11)\end{array}$ & $3.378^{\prime}$ & 0.021 \\
\hline $\begin{array}{l}\mathrm{K} \\
(\mathrm{cmoles} / \mathrm{kg})\end{array}$ & $\begin{array}{l}0.2- \\
0.3^{c}\end{array}$ & $\begin{array}{l}0.45-2.20 \\
(0.96 \pm 0.21)\end{array}$ & $\begin{array}{l}0.24-2.07 \\
(0.98 \pm 0.22)\end{array}$ & $\begin{array}{l}0.23-3.52 \\
(1.05 \pm 0.38)\end{array}$ & $\begin{array}{l}0.44-1.46 \\
(0.83 \pm 0.15)\end{array}$ & $\begin{array}{l}0.56-1.44 \\
(0.93 \pm 0.16)\end{array}$ & $0.110^{\prime}$ & 0.978 \\
\hline $\begin{array}{l}\mathrm{Na} \\
(\mathrm{cmoles} / \mathrm{kg})\end{array}$ & & $\begin{array}{l}0.10-0.30 \\
(0.16 \pm 0.03)\end{array}$ & $\begin{array}{l}0.10-0.29 \\
(0.20 \pm 0.02)\end{array}$ & $\begin{array}{l}0.01-0.67 \\
(0.23 \pm 0.08)\end{array}$ & $\begin{array}{l}0.01-0.32 \\
(0.12 \pm 0.04)\end{array}$ & $\begin{array}{l}0.13-0.26 \\
(0.18 \pm 0.03)\end{array}$ & $0.932^{\prime}$ & 0.458 \\
\hline Sand $(\%)$ & & $\begin{array}{l}58.00-74.00 \\
(64.38 \pm 1.91)\end{array}$ & $\begin{array}{l}51.00-66.00 \\
(60.25 \pm 1.97)\end{array}$ & $\begin{array}{l}33.00-76.00 \\
(61.25 \pm 4.90)\end{array}$ & $\begin{array}{l}57.00-78.00 \\
(67.50 \pm 2.30)\end{array}$ & $\begin{array}{l}52.00-65.00 \\
(60.40 \pm 2.32)\end{array}$ & $1.092^{\prime}$ & 0.377 \\
\hline Clay (\%) & & $\begin{array}{l}12.00-28.00 \\
(18.00 \pm 2.06)\end{array}$ & $\begin{array}{l}17.00-34.00 \\
(26.25 \pm 2.10)\end{array}$ & $\begin{array}{l}13.00-49.00 \\
(24.13 \pm 3.94)\end{array}$ & $\begin{array}{l}8.00-29.00 \\
(19.13 \pm 2.13)\end{array}$ & $\begin{array}{l}25.00-35.00 \\
(28.80 \pm 1.69)\end{array}$ & 2.793' & 0.043 \\
\hline Silt (\%) & & $\begin{array}{l}11.00-24.00 \\
(17.63 \pm 1.75)\end{array}$ & $\begin{array}{l}7.00-20.00 \\
(13.50 \pm 1.30)\end{array}$ & $\begin{array}{l}7.00-22.00 \\
(14.63 \pm 2.03)\end{array}$ & $\begin{array}{l}11.00-15.00 \\
(13.38 \pm 0.63)\end{array}$ & $\begin{array}{l}8.00-13.00 \\
(10.80 \pm 0.97)\end{array}$ & $2.422^{\prime}$ & 0.069 \\
\hline $\begin{array}{l}\mathrm{Ca} / \mathrm{Mg} \\
\text { ratio }\end{array}$ & & $\begin{array}{l}0.20-0.71 \\
(0.38 \pm 0.06)\end{array}$ & $\begin{array}{l}3.68-4.17 \\
(4.00 \pm 0.06)\end{array}$ & $\begin{array}{l}3.75-4.76 \\
(4.14 \pm 0.12)\end{array}$ & $\begin{array}{l}0.08-0.37 \\
(0.24 \pm 0.04)\end{array}$ & $\begin{array}{l}2.00-2.50 \\
(2.26 \pm 0.11)\end{array}$ & $612.288^{\prime}$ & 0.000 \\
\hline
\end{tabular}

${ }^{\mathrm{a}}$ Lagu et al.(2017); ${ }^{\mathrm{b}}$ Bowden et al. (2013); ${ }^{\mathrm{c}} \operatorname{Cook}(2014)$.

The texture of soils of the study districts comprised mainly of sand which constituted the highest percentage ranging from 60.25 to67.50\% in Ibanda and Isingiro districts respectively. This was followed by clay which fluctuated between 18.00 and $28.80 \%$ in Kiruhura and Sheema respectively. Silt had the least content ranging from10.80 to $17.63 \%$ in Sheema and Kiruhura respectively. It was observed that $\mathrm{pH}, \mathrm{OM}, \mathrm{N}, \mathrm{Ca}, \mathrm{Mg}$ and clay levels varied in the study districts ( $p<0.05)$. Sandy soils with an overall mean of $62.76 \%$ was the highest $(F=270.433, p<0.05)$ followed by clay $(23.26 \%)$ and silt (13.99\%).

The study found out that Kiruhura district had the highest levels of essential soil nutrients (N, P) above the critical levels which tally with the high quantity of Chloris gayana seeds harvested per acre in the district. On the other hand, Sheema district with the least quantity of seeds harvested per acre had N and P concentrations below the critical levels. Similarly Kiruhura district with higher $\mathrm{N}$ and $\mathrm{P}$ nutrients than Mbarara also had more hay bales (Kg) harvested per acre than Mbarara (Table 1).

The Pearson's correlation matrix for the mean quantity of seeds harvested per acre and the soil 
parameters in the five districts is shown in Table 2. Soil $\mathrm{pH}, \mathrm{Na}$ and sand content exhibited a very weak positive correlation with quantity of Chloris gayana seeds harvested per acre $(\mathrm{p}>0.05)$. Organic matter $(\mathrm{OM})$ and $\mathrm{Ca}$ had a very weak negative correlation with Chloris seed yield while clay content had a moderate negative correlation with the seed yield ( $p>0.05)$.

Table 2: Pearson's correlation (r) matrix for the mean quantity of Chloris gayana seeds harvested per acre and the soil parameters in the five districts

\begin{tabular}{|c|c|c|c|c|c|c|c|c|c|c|c|}
\hline Parameters $(\mathrm{N}=5)$ & $\mathrm{pH}$ & $\mathrm{OM}$ & $\mathrm{N}$ & $\mathrm{P}$ & $\mathrm{Ca}$ & $\mathrm{Mg}$ & $\mathrm{K}$ & $\mathrm{Na}$ & Sand & Clay & Silt \\
\hline Seed harvested/acre & 0.016 & -0.158 & 0.468 & 0.778 & -0.034 & 0.427 & 0.509 & 0.211 & 0.125 & -0.572 & $0.911^{*}$ \\
\hline $\mathrm{pH}$ & & 0.763 & -0.622 & 0.364 & $0.959^{*}$ & -0.522 & 0.709 & 0.776 & -0.630 & 0.406 & 0.039 \\
\hline $\mathrm{OM}$ & & & $-0.935^{*}$ & -0.132 & $0.913^{*}$ & $-0.914^{*}$ & 0.754 & $0.926^{*}$ & -0.863 & 0.790 & -0.382 \\
\hline $\mathrm{N}$ & & & & 0.379 & -0.785 & $0.987^{* *}$ & -0.512 & -0.759 & 0.869 & $-0.945^{*}$ & 0.664 \\
\hline $\mathrm{P}$ & & & & & 0.177 & 0.408 & 0.469 & 0.200 & -0.005 & -0.475 & $0.893^{*}$ \\
\hline $\mathrm{Ca}$ & & & & & & -0.712 & 0.783 & $0.895^{*}$ & -0.752 & 0.575 & -0.121 \\
\hline $\mathrm{Mg}$ & & & & & & & -0.519 & -0.755 & $0.893^{*}$ & $-0.966^{* *}$ & 0.672 \\
\hline K & & & & & & & & $0.946^{*}$ & -0.727 & 0.343 & 0.280 \\
\hline $\mathrm{Na}$ & & & & & & & & & -0.852 & 0.596 & -0.034 \\
\hline Sand & & & & & & & & & & -0.865 & 0.349 \\
\hline Clay & & & & & & & & & & & -0.772 \\
\hline
\end{tabular}

There was modest to strong positive correlation of quantity of seeds per acre with N, P, Mg and $\mathrm{K}$ ( $\mathrm{p}>0.05)$. Silt content exhibited a very strong positive correlation with quantity of Chloris gayana seeds harvested per acre $(\mathrm{p}<0.05)$.

\section{DISCUSSION}

4.1 Chloris gayana yields in relation to soil parameters across the south Western zone of Uganda

Basing on Bruce and Rayment (1982) and Horneck et al. (2011), the mean soil pH of the study districts varied from moderately acidic (Kiruhura, Isingiro, Sheema) to neutral (Ibanda, Mbarara), suitable for growth of Chloris gayana. According to Abebe et al. (2015), Rhodes grass has some establishment problems on very acidic soils. Chloris gayana grows best in soils with $\mathrm{pH}$ between about 5.5 and 7.5 but also can grow at $\mathrm{pH} 4.5$ up to 10 (Cook, 2007). However, it is more tolerant to high $\mathrm{pH}$ than low $\mathrm{pH}$. Basing on Fowler et al. (1998), the very weak positive correlation of yield of Chloris gayana (quantity of seeds per acre) and $\mathrm{pH}(\mathrm{p}>0.05)$ shows that Chloris gayana thrives better in slightly high $\mathrm{pH}$ than low $\mathrm{pH}$ (Table 2). The mean $\mathrm{pH}$ range of soils in the study areas(5.86-6.79) was favourable to readily avail the nutrients $(\mathrm{N}, \mathrm{P}, \mathrm{K}, \mathrm{Ca}, \mathrm{Mg}$ ) into the soils (Hazelton \& Murphy, 2007) for the growth of Chloris gayana. 
Basing on Hazelton and Murphy (2007), the soils in the study districts had very high sand contents suitable for the growth of Chloris gayana while silt contents were low. Clay content ranged from low (Kiruhura, Mbarara, Isingiro) to moderate (Ibanda, Sheema). Cameron (1967), Bogdan (1969) and Loch (1980) reported that Rhodes grass grows best on fertile sandy textured soils. Grubb $(1986,1987)$ further asserted that grasses including Rhodes grass grow in sandy and silty areas. On the other hand, Chloris gayana does not grow well on very heavy clays (Cook, 2007; Valenzuela \& Smith, 2002). This is augmented by the very strong positive correlation of silt with the quantity of Chloris gayana seeds harvested per acre $(\mathrm{p}<0.05)$ and the very weak positive correlation of the seed yield with sand $(\mathrm{p}>0.05)$. Additionally, the negative correlation of clay content with the seed yield ( $>>0.05)$ justifies the unsuitability of clay soil for the growth of Chloris gayana.

The variations in the seed and bale yields per acre may majorly be attributed to variations in soil fertility (quantity of macronutrients) of the study districts. Basing on the ratings of total nitrogen (Bruce and Rayment, 1982), the mean nitrogen contents in soils in Kiruhura, Isingiro were very high. Mbarara, Ibanda and Sheema soils had high, medium and low N contents respectively. On the other hand, using Tekalign et al. (1991), Kiruhura, Isingiro and Mbarara had high N contents, Ibanda contained moderate levels while Sheema also recorded low $\mathrm{N}$ concentration.

Using Espinoza et al. (n.d.), categorization, P levels were medium in Kiruhura and Ibanda, low in Mbarara and Isingiro and very low in Sheema district. Basing on the levels of exchangeable cations by Metson (1961), mean $\mathrm{Na}$ in all the study districts was low. Mean $\mathrm{K}$ and $\mathrm{Mg}(\mathrm{mg} / \mathrm{kg})$ in the study areas ranging from 323.78 to $409.61 \mathrm{mg} / \mathrm{kg}$ and 277.13 to $870.30 \mathrm{mg} / \mathrm{kg}$ respectively were very high using Tekalign et al. (1991) guidelines of $\mathrm{K}$ and $\mathrm{Mg}$ in soils. On the other hand, mean Ca levels were very low in Kiruhura $(480.96 \mathrm{mg} / \mathrm{kg}$ ) and Isingiro $(324.65 \mathrm{mg} / \mathrm{kg})$, medium in Sheema (1022.04 mg/kg) and very high in Ibanda $(2605.20 \mathrm{mg} / \mathrm{kg}$ ) and Mbarara $(2557.104$ $\mathrm{mg} / \mathrm{kg}$ ) districts basing on Tekalign et al. (1991) guidelines. Hence soils in Kiruhura and Isingiro districts were $\mathrm{Ca}$ deficient, Sheema had low $\mathrm{Ca}$ while Ibanda and Mbarara districts had balanced $\mathrm{Ca}$ and $\mathrm{Mg}$ concentrations from $\mathrm{Ca} / \mathrm{Mg}$ ratio categorization by Eckert (1987).

Kiruhura soils had higher amounts of the essential nutrients (N, P) than soils of Sheema (Table 1). Additionally the levels of nutrients $(\mathrm{N}, \mathrm{P})$ in Kiruhura were above the critical levels i.e. nutrient concentrations that are just adequate for maximum growth of Chloris gayana (Bowden et al., 2013; Cook, 2014; Ulrich, 1952). On the other hand, soils in Sheema district had N and P concentrations below the critical values. In general, grasses such as Chloris gayana have a high requirement for N, P and K. Chloris gayana gives improved yields under phosphorus and usually a spectacular yield under nitrogen in the presence of adequate phosphorus and potassium (Abebe et al. 2015). The quantity of Chloris gayana seeds harvested per acre was high under increased amounts of $\mathrm{N}, \mathrm{P}$ and $\mathrm{K}$ in the study districts and this was further supported by the modest to strong positive correlation of quantity of Chloris gayana seeds harvested per acre with N, P and $\mathrm{K}(\mathrm{p}>0.05)$. This demonstrates the necessity of these mineral nutrients for the productivity of Chloris gayana grass in the study districts.

The generally low productivity of Rhodes grass in the study districts despite high levels of most of the essential nutrients $(\mathrm{N}, \mathrm{P}, \mathrm{K})$ was also attributed to the prolonged drought experienced 
during the study period, February 2015 to February 2016 (Lagu et al., 2017). For instance, Meteorological report for August 2015, showed that some districts in southern corridor of Uganda such as Isingiro, Kiruhura and parts of Ntungamo, among others experienced the driest conditions (with rainfall amounts below $250 \mathrm{~mm}$ ) that resulted into reduction of animal pasture (Ministry of Water and Environment, 2015). The rainfall received during this month was much lower than the optimum average annual rainfall $(600-1,000 \mathrm{~mm})$ required for the growth of Rhodes grass (Valenzuela \& Smith, 2002).

The variations in the amounts of $\mathrm{Ca}, \mathrm{Mg}$, and $\mathrm{Na}$ in soils of the various districts may not be a serious issue as opposed to levels of N, P, K. According to Horneck et al. (2011), few crops have increased growth or yield from calcium and magnesium additions and high levels of sodium are detrimental to soil structure, soil permeability, and plant growth (Horneck et al., 2011).

The higher seed yield in Kiruhura than in Sheema may also be attributed to relatively more favourable soil $\mathrm{pH}$ conditions and soil texture. Much as soils in both Kiruhura and Sheema districts were moderately acidic according to the $\mathrm{pH}$ interpretation by Bruce and Rayment (1982) and Horneck et al. (2011), pH was slightly higher in Kiruhura soils than Sheema soils. Basing on Hazelton and Murphy (2007), Kiruhura had low clay content while Sheema had moderate amounts of clay which hindered growth of Chloris gayana.

Using the categorization of OM by Emerson (1991), the mean soil OM in Kiruhura and Isingiro districts were extremely low, Sheema recorded moderate levels while Ibanda and Mbarara had high organic matter. The high $\mathrm{N}$ and $\mathrm{P}$ levels in Kiruhura soils with low OM content and high Chloris gayana seed yield per acre points to increased OM decomposition to release N, P, K into the soil for increased productivity of Chloris gayana. According to Lavelle and Spain (2001), organic matter decomposition is the source of most of the nitrogen and phosphorus in unfertilised soils. This is further supported by the negative correlation of OM with $\mathrm{N}(\mathrm{p}<0.05)$ and the very weak negative correlation of OM with $\mathrm{P}(\mathrm{p}>0.05)$ and of $\mathrm{OM}$ with Chloris gayana seeds harvested per acre $(\mathrm{p}>0.05)$ as shown in Table 2.

The higher yields of Chloris gayana seeds in Kiruhura District is further explained by the fact that the lands in the district have been under fallow for many years and the farmers are mainly traditional cattle keepers who are less engaged in crop cultivation in the past years. Hence there has been encroachment of Kiruhura lands by mainly bushes and shrubs, due to overgrazing and soil trampling by cattle kept in the grazing areas. Yet, also over the years, organic matter rich manure from the cows through their cow dung kept dropping in the grazing paddocks boosting the soil fertility levels of the soils in Kiruhura district compared to Sheema etc. Organic matter in the soil is directly derived from plants and animals (Horneck et al., 2011). It is largely responsible for much of the chemical fertility of a soil through its breakdown (Allison, 1973; Charman and Roper 2007).

Generally, the levels of organic matter (OM) in soils from the studied districts ranging from 0.16$4.38 \%$ were quite low. According to Shoji (1988) organic matter makes notable contribution to soil properties if the organic carbon content exceeds 6 percent. The low organic matter content in 
the soils can be attributed to higher composition of sandy soils than clay and silt contents in soils of the various districts. According to Dregne (1976), sands contain very low organic-matter content. The little organic matter in the sand dominated soils might have been absorbed by clay which has low rate of decomposition of organic matter. According to Dregne and Maker (1955) and Dregne (1976), the rate of decomposition of organic matter is less in clays than in sands. Fine-textured soils (clay) have a much greater surface area and are capable of absorbing more organic matter than coarse-textured soils (sand). This is confirmed by the strong positive correlation between OM and clay ( $\mathrm{p}>0.05$ ) and very strong negative correlation of OM with sand $(\mathrm{p}>0.05)$.

In soils, potassium may be fixed on to 2:1 clays in non-exchangeable forms in addition to largely entering through the weathering of minerals like micas, feldspars, etc (Lavelle \& Spain, 2001). Hence the weak positive correlation of $K$ with clay soils in this study ( $p>0.05)$ supports the fact that $\mathrm{K}$ is partly fixed by clay.

The range of the mean levels of $\mathrm{Na}(0.0028-0.0053 \%), \mathrm{K}(0.032-0.041 \%), \mathrm{Mg}(0.028-0.087 \%)$, $\mathrm{Ca}(0.032-0.256 \%)$ and $\mathrm{P}(0.0014-0.0034 \%)$ in soils of the study districts were much lower than the concentrations of these minerals in Chloris gayana grown in Queen Elizabeth National Park, western Uganda of $0.041 \%, 1.17 \%, 0.15 \%, 0.29 \%$ and $0.22 \%$ respectively (Harrington \& Pratchett, 1973; Long et al., 1969; Long et al., 1970).The higher levels of the nutrients in Chloris gayana than in soils from the study districts is in agreement with the findings of Lavelle and Spain (2001) that vegetation biomass may sometimes have higher nutrient element stocks than levels in highly weathered soils. Klinge in Salati and Vose (1984) found higher stocks of Ca, $\mathrm{Mg}$ and $\mathrm{K}$ in the phytobiomass than in soils in a highly weathered Amazonian rainforest ecosystem.

The very strong positive correlation of $\mathrm{Ca}$ and $\mathrm{Na}$ with organic matter $(\mathrm{p}<0.05)$ and the weak to strong positive correlation of $\mathrm{K}, \mathrm{Na}$ and $\mathrm{Ca}$ with clay as well as $\mathrm{K}$ with organic matter ( $p>0.05)$ points to the retention of some of the $\mathrm{Ca}, \mathrm{Na}$ and $\mathrm{K}$ at the colloidal surfaces of clay and organic matter. According to Lavelle and Spain (2001), much of the readily available basic cations (Ca, $\mathrm{Mg}$, and $\mathrm{K}$ ) for plants are retained at colloid surfaces (largely clay particles or organic matter) and may be held in a state of equilibrium with cations in the soil solution in non-calcareous soils. On the other hand the negative correlation of $\mathrm{Mg}$ with clay and organic matter $(\mathrm{p}<0.05)$ points to the fact that it was not retained on clay and organic matter but rather exists free in the soil like $\mathrm{N}$ and $\mathrm{P}$ hence the positive correlation of $\mathrm{Mg}$ with $\mathrm{N}(\mathrm{p}<0.05)$ and the modest positive correlation of Mg with P (p>0.05). This is contrary to the findings of Lavelle and Spain (2001) possibly due to variations in soil mineral composition, $\mathrm{pH}$, temperature, moisture content etc in soils of the studied districts.

\section{CONCLUSIONS}

The highest quantity of seeds and biomass of grass per acre is attained if only all the essential primary soil nutrients (NPK) are above the critical levels.

Soils with low N concentrations in Ibanda, Mbarara and Sheema districts and low P content in Sheema i.e. all below the critical levels may require fertiliser application to increase the levels of 
these nutrients so as to boost the productivity of Chloris gayana in those districts.

Efforts towards soil testing and soil amendments need to be intensified for increased productivity of Chloris gayana in South Western Uganda.

\section{Acknowledgement}

The authors acknowledge the support from National Agricultural Advisory Services, Local Government from participating districts, Mbarara Zonal Agricultural Research and Development Institute (MbaZARDI), Staff of Ministry of Agriculture Animal Industry and Fisheries (MAAIF) and beneficiary farmers from eight districts who were involved in the study.

\section{REFERENCES}

Abebe, Y, Tafere, M, Dagnew, S, Tolla, M, Selassie, Y G, Amane, A and Molla, D (2015). Best Fit Practice Manual for Rhodes Grass (Chloris Gayana) Production. BDU-CASCAPE working $\quad$ paper 10 http://www.bdu.edu.et/sites/default/files/10\%20Rhodes\%20grass\%20manual_0.pdf Retrieved 9 ${ }^{\text {th }}$ May 2018.

African Centre for Economic Transformation, ACET, 2017. African Transformation Report 2017, Agriculture Powering Africa's Economic Transformation "Transforming Africa's Rural Economy - Uganda, 'Putting the beef in Uganda's meat industry'. Retrieved from https://www.ntusbfcas.com/african-business-insights/content/putting-the-beef-in-uganda-smeat-industry Retrieved on 23rd Feb 2018.

Allison, F. E. (1973). 'Soil Organic Matter and its Role in Crop Production.' (ElsevierScientific Publishing Company: London.)

Arshad, I., Medani K.M., \&Khan Z.A (2016).Integrated Impact of Nitrogen and Phosphorus on Rhodes Grass under Ghotki Environment.J Agric. Res., 54(4):687-695.

Arshad, I.,Medani K.M., \&Khan Z.A (2014) "Effect of manual and artificial application of NPK fertilizers on the growth and yield of Rhodes Grass (Chloris gayana L. Kunth.) by using central pivot irrigation technology”. Int. J. of Res. 1(7), ISSN:2348-6848.

Bogdan, A. V., (1961). Intra-variety Variation in Rhodes grass (Chloris gayana Kunth) in Kenya. Journal of the British Grassland Society; Black well Publishing Limited pp 238-239.

Bogdan, A. V., (1969). Rhodes grass: Herb Abstract. Common wealth agricultural bureau 39: 1 13.

Bowden, B., Valentine, C \& Moore, G (2013). What is the mineral nutrient status of perennial grasses in the Northern Agricultural Region? Evergreen pasture updates. http://evergreen.asn.au/wp-content/uploads/2015/04/What-is-the-mineral-nutrient-status-ofperennial-grasses-in-the-NAR-Bill-Bowden.compressed.pdfRetrieved on 9th May 2018.

Bruce, R. C., and Rayment, G. E. (1982). Analytical methods and interpretations used by the Agricultural Chemistry Branch for Soil and Land Use Surveys. Queensland Department of Primary Industries. Bulletin QB8 (2004), Indooroopilly, Queensland.

Cameron, D.G., 1967. Rhodes grass still a major sown pasture. Queensl. Agric. J., 93: 528-536.

Charman, P. E. V., and Roper, M. M. (2007).Soil organic matter.In 'Soils - theirproperties and management'.3rd edn. (Eds P. E. V. Charman and B. W. Murphy.) pp. 276-285. (Oxford University Press: Melbourne.) 
Vol. 4, No. 05; 2019

ISSN: $2456-8643$

Cook, B.G. (2007). Factsheet-Rhodes grass. Pastures

Australia.https://keys.lucidcentral.org/keys/v3/pastures/Html/Factsheet\%20-

\%20Rhodes\%20grass.pdf Retrieved on 9th May 2018.

Cook, B.G., Pengelly, B.C., Brown, S.D., Donnelly, J.L., Eagles, D.A., Franco, M.A., Hanson, J., Mullen, B.F., Partridge, I.J., Peters, M. and Schultze-Kraft, R. 2005. Tropical Forages: an interactive selection tool. [CD-ROM], CSIRO, DPI\&F (Qld), CIAT and ILRI, Brisbane, Australia.

Cook, S (2014). Interpreting Soil Test Information. Queensland Murray-Darling Committee Inc. http://www.qmdc.org.au/module/documents/download/2461 Retrieved on 9th May 2018.

Dinkins, C P., and Jones C (2013). MT200702AG. Interpretation of Soil Test Reports for Agriculture.Montana State University Extension.

Dregne H.E. (Ed.) (1976). Developments in soil science 6: Soils of Arid Regions-Elsevier Scientific Pub. Co., Amsterdam, Netherlands.

Dregne, H.E. and Maker, H.J., 1955. Fertility levels of New Mexico soils. N.M. Agric. Exp. Stn., Bull., No. 396.

Eckert, D. J. (1987). Soil test interpretations. Basic cation saturation ratios and sufficiency levels. In 'Soil testing: Sampling, correlation, calibration and interpretations'. SSSA Special Publication No.21. (Ed. J. R. Brown.) pp. 53-64. (Soil Science Society of America: Madison, USA.)

Emerson, W. W. (1991). Structural decline of soil, assessment and prevention.Australian $s$ Journal of Soil Research 29, 905-922.

Espinoza, L., Slaton, N., Mozaffari, M. (n.d.). FSA2118. Understanding the Numbers on Your Soil Test Report: University of Arkansas Cooperative Extension Service Printing Services. Retrieved from https://www.uaex.edu/publications/PDF/FSA-2118.pdf 9th May 2018.

Fowler, J, Cohen, L \& Jarvis, P (1998).Practical Statistics for Field Biology. Second edition.John Wiley \& Sons publishers. Chichester, England.

Grubb, P. J. (1986). The ecology of establishment. In Ecology and Design in Landscape, ed. A. D. Bradshaw, D. A. Goode \& E. Thorp, pp. 83-98. Oxford: Blackwell.

Grubb, P. J. (1987). Some generalizing ideas about colonization and succession in green plants and fungi. In Colonization, Succession and Stability, ed. A. J. Gray, M. J. Crawley \& P. J. Edwards, pp. 81-102. Oxford: Blackwell.

HARC (Holetta Agricultural Research Center), 2004. Feed Resources Development and Utilization: Possible Options and Recommendations Under Ethiopia Condition.

Harrington, G.N. and Pratchett, D. 1973. Cattle diet on Ankole rangeland at different seasons. Trop. Agric. Trin. 49:211-219.

Hazelton P and Murphy B L (2007). Interpreting Soil Test Results: What Do All the Numbers Mean? CSIRO Publishing, Collingwood, Australia.

Horneck D A., Sullivan, D.M., Owen, J.S., and Hart J.M. (2011).Soil Test Interpretation Guide.Oregon State University.

ICPALD, IGAD Center for Pastoral Areas \& Livestock Development (2013).The Contribution of Livestock to the Ugandan Economy [ICPALD 7/CLE/8/2013].Nairobi, Kenya. https://igad.int/attachments/714 The\%20Contribution\%20of\%20Livestock\%20to\%20the\%2 0Ugandan\%20Economy.pdf Retrieved ${ }^{\text {th }}$ May 2018. 
Kashaigili, J.J., Zziwa, E., Ernest, S., Laswai, E., Segatagara, B. M., Mpairwe, D., ...Kadigi, I. L. (2015): Implications of Land Use Land Cover Change and Climate Variability on Future Prospects of Beef Cattle Production in the Lake Victoria Basin. American Journal of Climate Change, 4, 461-473. http://dx.doi.org/10.4236/ajcc.2015.45037

Lagu, C., Andama, M.,Mugasi, S. K. \&Nsemerirwe, T (2017).Causing Revolution in Pasture Development for Increased Livestock Production and Productivity in South Western Uganda, International Journal of Leadership, Education and Business Studies (IJLEBS), 2(1), 53-64.

Lavelle, P and Spain, A. V. (2001).Soil Ecology.Kluwer Academic Publishers, New York.

Loch, D. S (1980). Seed assures future of Callide Rhodes. Queensl. Agric J. 106: 183-187.

Long, M.I.E., Ndyanabo, W.K., Marshall, B. and Thornton, D.D. 1969.Nutritive value of grasses in Ankole and the Queen Elizabeth National Park, Uganda. IV. Mineral content. Trop. Agric. (Trin.) 46:201-209.

Long, M.I.E., Thornton, D.D., Ndyanabo, W.K., Marshall, B. and Ssekaalo, H. 1970.The mineral status of dairy farms in the parts of Buganda and Busoga bordering Lake Victoria, Uganda. II - Nitrogen and mineral content of pastures. Trop. Agric. (Trin.) 47:37-50.

MAAIF (2010).Agriculture for Food and Income Security: Agriculture Sector Development Strategy and Investment Plan: 2010/11- 2014-15. Entebbe, Uganda. http://www.fao.org/fileadmin/user_upload/drought/docs/Agriculture_DSIP\%20Uganda1.pdf Retrieved $9^{\text {th }}$ May 2018.

Marschner, H. (1995) Mineral Nutrition of Higher Plants, Academic Press, London.

Mbabazi, M.C. \& Ahmed, M., 2012.Analysis of incentives and disincentives for beef in Uganda. Technical notes series, MAFAP, FAO, Rome.

Ministry of Water and Environment (2015).September to December 2015 Seasonal Rainfall Outlook over Uganda. Kampala, Uganda. Press Release, APS/130/141/146/03.

Mwale, O (1993). Nutritive Value of Rhodes Grass at DifferentGrowth Stages for Ruminant Production. PhD Thesis (Unpublished). The University of Zambia, Unza, Lusaka, Zambia.

Nanzyo, M., Dahlgren, R. \& Shoji, S. (1993). Chemical Characteristics of Volcanic Ash Soils. In:Shoji S, Nanzyo, M, Dahlgren, R A (Eds.), Volcanic ash soils: genesis, properties, and utilization (pp. 145-187). Elsevier, Amsterdam, Netherlands: Developments in soil science 2

Okalebo, J.R., Gathua, K.W. and Woomer, P.L. (2002) Laboratory Methods for Soil and Plant Analysis: A Working Manual.Second Edition, TSBF-CIAT and SACRED Africa, Nairobi.

Osman, AA M., Aziz, A A H A., Babiker, F S H (2014). A Comparative Study between Rhodes Grass (Chloris gayana Kunth) with Local Grass Forages. Universal Journal of Agricultural Research 2(2): 50-55.

Reed, C.F. 1976. Information summaries on 1000 economic plants. Typescripts submitted to the USDA.

Ryan, J., Estefan,G., and Rashid, A. (2001).Soil and plant analysis lab manual.2nd ed. International Center for Agricultural Research in the Dryland Areas(ICARDA), Aleppo, Syria. National Agricultural Research Center, Islamabad,Pakistan.

Salati, E. and Vose, P.B. (1984) Amazon Basin: a system in equilibrium. Science, 225, 129-38.

Shoji, S., 1988.Separation of melanic and fulvicAndisols. Soil Sci. Plant Nutr., 34: 303-306.

Tekalign, T., Haque, I., and Aduayi, E.A (1991).Soil, plant, water, fertilizer, animal manure and compost analysis manual.Plant Science Division Working Document 13, ILCA, Addis Ababa, Ethiopia. 
Uganda Investment Authority (UIA). 2009. Uganda: Livestock Sector Brief. Uganda Investment Authority, Kampala. Uganda. www.ugandainvest.com

Ulrich, A. (1952). Physiological bases for assessing the nutritional requirements of plants. Ann. Rev. Plant. Physiol. 3:207-228.

Valenzuela, H \& Smith, J (2002).Rhodes grass.Sustainable Agriculture Cover Crops, SA-CC-3, College of Tropical Agriculture and Human Resources (CTAHR), University of Hawai'i, Mānoa.https://www.ctahr.hawaii.edu/oc/freepubs/pdf/CoverCrops/rhodesgrass.pdfRetrieved on 9th May 2018.

World Bank (2011).Uganda: Agriculture for Inclusive Growth in Uganda. Draft Final Report. http://siteresources.worldbank.org/INTDEBTDEPT/Resources/4689801316457581843/CaseStudy_Uganda_02.pdf Retrieved $9^{\text {th }}$ May 2018. 